See discussions, stats, and author profiles for this publication at: https://www.researchgate.net/publication/275562747

Decentralization, Institutional Ambiguity, and Mineral Resource Conflict in Mindanao, Philippines

Article in World Development · November 2014

Dol: 10.1016/j.worlddev.2014.11.007

CITATIONS

23

1 author:

Boris Verbrugge

KU Leuven

23 PUBLICATIONS 188 CITATIONS

SEE PROFILE

Some of the authors of this publication are also working on these related projects:
READS

275

InForMining. The informalization of global gold production? View project 


\section{DECENTRALIZATION, INSTITUTIONAL AMBIGUITY, AND MINERAL RESOURCE CONFLICT IN MINDANAO, PHILIPPINES}

Please refer to: Verbrugge, B. (2015). Decentralization, institutional ambiguity, and mineral resource conflict in Mindanao, Philippines. World Development, 67, 449-460.

\section{INTRODUCTION}

In recent years and decades, decentralization has emerged as a major policy emphasis worldwide, stimulating debates about the relationship between decentralization and various aspects of governance and economic development, including public accountability and corruption, poverty alleviation, intergovernmental fiscal relations, and the nature of political competition (see Faguet, 2014 for an overview). In development studies, specific attention has been paid to effectivity and equity concerns in the decentralization of natural resource management (Larson \& Ribot, 2004), particularly in the domain of forestry (e.g. Larson \& Ribot, 2004; Andersson, Gibson \& Lehoucq, 2005; Batterburry \& Fernando, 2006). A recurring argument in this body of literature is that otherwise well-intentioned decentralization initiatives are often thwarted by political-economic considerations, with national governments "recentralizing while decentralizing" (Ribot, Agrawal and Larson, 2006), and local elites capturing newly devolved powers and resources (Béné et al., 2009; Maconachie, 2010; Pattenden, 2011; Poteete and Ribot, 2011).

A somewhat underdeveloped theme in the growing body of literature on decentralization is its alleged potential to mitigate or even prevent conflict (Lijphart, 1977). A growing number of scholars has warned against an overly optimistic reading of the relationship between decentralization and sociopolitical stability. These scholars can roughly be categorized in two groups. A first group is associated with the political science literature on civil conflict, and aims to identify the variables that mediate the relationship between decentralization (whether or not as part of a broader system of federalism) and intrastate stability at the macro level (Kymlicka, 1998; Brancati, 2008). A second group of scholars is more closely associated with 
critical development studies, and argues that decentralization increases institutional uncertainty, thereby producing conflicts between a range of actors staking competing claims to resources (Mccarthy, 2004; Peluso, 2007; Benjamin, 2008; Hagmann and Mulugeta, 2008).

Identifying with this second group of authors, this article adopts an empirical, bottom-up approach to analyzing the impact of decentralization on mineral resource governance -a theme that has hitherto received only scant attention in the decentralization literature (but see Maconachie, 2009; Arellano-Yanguas, 2011)- in the Philippines. Section two of the article provides a more elaborate review of the existing literature that deals with the relationship between decentralization and intrastate conflict. It also proposes an analytical framework to analyze the impact of decentralization on local resource conflicts, that draws heavily on insights from the literature on incremental institutional change (particularly Mahoney \& Thelen, 2009). Section three provides a critical historical overview of central-local ties and decentralization in the Philippines. It is argued that the Local Government Code of 1991, as the centerpiece of decentralization, was in fact a radicalization of a longstanding tradition of decentralized statebuilding through local politicians. Finally, section four presents the main empirical findings. It is argued that various, seemingly uncoordinated efforts to decentralize mineral resource governance, have given rise to a highly ambiguous institutional arena, marked by pervasive uncertainty regarding rule interpretation and -enforcement. This institutional ambiguity creates opportunities for the renegotiation and contestation of institutional arrangements, and the associated distribution of mineral resource wealth across society. This institutional renegotiation is a political process par excellence, and involves a range of conflicts between indistinct, asymmetric, and constantly shifting coalitions of actors that involve amongst others government officials, large-scale mining companies, small-scale miners, tribal groups, and armed groups. In an attempt to make sense of this complex conflict ecology, three major cleavages are identified around which institutional struggles are now crystallizing, namely (1) Intra-government conflicts over fiscal-regulatory authority in the 
mining sector, (2) Conflicts between large-scale mining companies and small-scale mining over access to mineral-yielding land, and (3) Conflicts between tribal groups seeking to secure ancestral domain rights and associated mining royalties under the Indigenous People's Rights Act. The common denominator underlying these different conflicts is the central role played by local politicians as gatekeepers in the mining sector. While it is impossible to predict future trajectories of institutional change, it is highly likely that they will continue to do so in the future. This raises important concerns over elite capture of the decentralization process.

\section{TOWARDS AN ANALYTICAL FRAMEWORK}

Decentralization is understood here broadly as "the transfer of power from the central government to actors and institutions at lower levels in a political-administrative and territorial hierarchy" (Larson \& Ribot, 2004, p. 3). National policy-makers can have various incentives to support the devolution of power and resources to subnational actors. Some authors treat decentralization as part of a long-term strategy aimed at shoring up the legitimacy and power of the regime (Boone, 2003), while others also draw attention to shortterm political considerations (Eaton, 2001). Rather than providing an in-depth discussion of the various arguments for and against decentralization, this theoretical section zooms in on one specific argument that has been coined in favor of decentralization, namely its alleged potential to prevent and/or to mitigate conflict. As noted in the introduction, existing theoretical-analytical approaches towards the relationship between decentralization and sociopolitical stability can roughly be categorized in two groups: one that focuses on macrolevel conflict, and one that draws analytical attention to micro-level political dynamics.

\subsection{Decentralization and intrastate stability on the macro-level}

The relationship between decentralization and sociopolitical stability has been extensively debated in the literature on civil conflict (for overviews see Bakke \& Wibbels, 2006; Brancati, 
2008). For some authors, decentralization reduces the likelihood of intrastate conflict, by enabling the inclusion of previously marginalized groups, thereby eliminating the grievances that fuel conflict (Lijphart, 1977). Others are more pessimistic, arguing that decentralization risks fostering centrifugal forces (Kymlicka, 1998), amongst others by providing subnational actors with the institutional structure and resources necessary to sustain (violent) mobilization (Snyder, 2000; Eaton, 2006). Still others argue that the relationship between decentralization and conflict is context-specific, and hinges on such key variables as interregional inequality and ethnic heterogeneity (Bakke \& Wibbels, 2006), or the presence of regional parties (Brancati, 2008).

Despite their disagreements, these authors share an analytical focus on the relationship between decentralization and conflict (mostly ethnic and secessionist conflict, but see Eaton, 2006) at the macro level. Furthermore, as noted by Brancati (2008), most of these authors draw on (comparative) qualitative case study material. A few others, including Brancati herself as well as Bakke and Wibbels (2006), use large- $\mathrm{N}$ statistical analysis to advance their theoretical claims. However, Bakke and Wibbels recognize the limits to the generalizability of their findings, stressing the need for "substantial case-study work to more carefully examine the mechanisms underpinning those findings" (p. 37-38).

\subsection{Views from below: decentralization and local resource struggles}

In recent years decentralization has attracted increased attention of a heterogeneous group of political anthropologists, human geographers, and development sociologists, who are primarily interested in understanding the impact of decentralization and democratization on local (resource) governance arrangements. Emerging from this body of literature are a series of related arguments about the intensely political character of decentralization, which all too often continues to be presented as a technocratic exercise (Hadiz, 2004). While some of these authors make notable efforts to develop an analytical framework, most are primarily 
interested in providing an in-depth analysis of decentralization within a particular sociopolitical context, usually based on extensive field research.

Several authors adopting such a bottom-up approach have convincingly demonstrated that in many countries, democratic decentralization is "barely happening" (Larson \& Ribot, 2004), or is subject to intense struggles between different government levels and -agencies over the eventual terms and extent of decentralization (Eaton, 2001). Particularly significant for the purposes of this article are those authors that draw attention to the tendency for decentralization to upset existing institutional arrangements that regulate access to natural resources, thereby creating opportunities for established or emergent elites to capture devolved power and resources (Béné et al., 2009; Pulhin and Dressler, 2009; Maconachie, 2010; Pattenden, 2011; Poteete and Ribot, 2011). In countries such as Ethiopia (Hagmann and Mulugeta, 2008) and Indonesia (Mccarthy, 2004; Peluso, 2007; Schulte Nordholt \& Van Klinken, 2007; Eilenberg, 2009), decentralization has gone hand in hand with an increase in conflicts over access to devolved power and resources between local elite networks. Significant for the purposes of this article, Arellano-Yanguas (2011) interrogates the impact of the new "localist paradigm" in the Peruvian mining sector, demonstrating how it has contributed to a range of conflicts over the distribution of mining rents. The following section aims to integrate these initial observations in a broader analytical framework for understanding the relationship between decentralization and local resource struggles.

\subsection{Towards an analytical framework}

The analytical framework proposed here draws heavily on insights from historical institutionalism, particularly on those authors working on incremental institutional change (Pierson, 2004; Mahoney \& Thelen, 2009). In line with other institutionalists, these authors conceive of institutions as formal and informal rules that structure human behavior. However, instead of seeing them as "neutral coordinating mechanisms", they are approached as "distributional arrangements that allocate resources unevenly" (Mahoney, 2010, p. 15) and 
that "reflect, and also reproduce and magnify, particular patterns of power distribution" (Thelen, 1999, p. 394). Moreover, while most institutionalists focus on exogenous shocks as sources of radical institutional change, these authors combine their power-laden approach to institutions with an analytical focus on incremental institutional change (Pierson, 2004; Mahoney \& Thelen, 2009). Finally, historical institutionalism would not be historical if it did not pay attention to the determining influence of institutional legacies on existing institutional arrangements, on the power relations underpinning them, and on the strategic choices available to (groups of) actors (Pierson, 2004). While important questions remain with regards to the contextual factors that promote or discourage particular trajectories of incremental institutional change, Thelen and Mahoney (2009) suggest that institutional change is particularly likely to occur in those environments characterized by high degrees of institutional ambiguity, where uncertainty over the interpretation and enforcement of existing rules creates opportunities for "agents of change" to assemble coalitions that seek to influence trajectories of change. Ultimately, a power-laden approach towards incremental institutional change draws central attention to "distributional conflict among aggregate actors as a basic driving force in history" (Mahoney, 2010, p. 15).

Approached from this perspective, the most important effects of decentralization may not necessarily lie in its sudden impact on institutional arrangements, but in the creation of longterm institutional ambiguity, which carries the seeds of incremental institutional change. In Mali, to name an example, decentralization has led to an "accumulation of several layers of powers with no single legitimacy and no longer any central institution capable of imposing its law and norms, thus greatly reducing the clarity of political processes" (Béné et al., 2009, p. 1945). Meanwhile in Indonesia, decentralization has also created a highly ambiguous institutional environment, characterized by "confusion about the distribution of power and authority between different levels of government" (Hadiz, 2004, p. 705). On the local level, this institutional ambiguity feeds into "highly volatile socio-legal configurations that create insecurity and heighten resource conflict" (Mccarthy, 2004, p. 1199) between different actors 
that are "competing, conflicting or colluding" (Béné et al., 2009, p. 1945), and capitalizing on divergent interpretations of the law to stake competing claims to power and resources. While these institutional conflicts and resource struggles unleashed by decentralization need not necessarily be destructive or disempowering, and can have important emancipatory effects (Ravikumar, Andersson and Larson, 2013), evidence so far suggests that they are mostly an elitist affair, which ultimately serves to exclude the end-users.

\subsection{Methodological challenges and choices}

The empirical data presented in this article was collected during more than 7 months of field research in the Philippines (January-February 2012, October-December 2013, and JanuaryMarch 2014), with a geographical focus on the eastern and southern portions of the conflictridden island of Mindanao. Here, a significant share of existing mining activities is currently taking place on an artisanal or small-scale basis. According to Heemskerk (2005), several obstacles hinder easy data collection in artisanal and small-scale mining (ASM) communities. These include sector-specific characteristics such as variable income and production levels and high levels of mobility. In the case of Mindanao, however, it is the political environment that poses the most immediate challenges. For one, as elsewhere, most small-scale miners operate on "the fringes of or completely outside the law" (Sinding, 2005, p. 244), which makes them wary of outside inquiry. Even more challenging is the presence of a range of armed actors, including communist rebels of the New People's Army (NPA), the armed wing of the Communist Party of the Philippines (for more background see Marks, 1996), the Armed Forces of the Philippines (AFP), and various paramilitary groups, all of which cultivate indistinct connections with mining interests and local politicians.

In addition to these methodological challenges, there is simply a dearth of existing empirical research on the situation in Philippine mining areas, or on the volatile history of eastern Mindanao for that matter (but see Abinales, 2000). Hence, this article draws on a combination of scarce existing literature, (online) media publications, and primary field 
research. More than 200 open-ended interviews were conducted with a wide variety of respondents. The selection of respondents in mining areas (mostly miners, financiers, landowners and local politicians) typically proceeded on the basis of 'snowball sampling', which taps local contacts and existing respondents to identify other respondents. Given the pioneering and highly sensitive nature of the research, data collection relied on a pragmatic methodological approach. Interviews with miners, upland settlers and financiers drew on insights from life-course methodology, which uses subjective life accounts as an analytical entry point to understand broader processes of political and institutional change (Locke and Lloyd-Sherlock, 2011). Particularly important for understanding the broader institutional context, however, were semi-structured key informant interviews with, amongst others, local politicians, national government staff, large-scale mining representatives, lawyers, and NGOworkers. While many interviews were held in English (still the language of instruction in the Philippines), an interpreter was present at all times.

\section{HISTORICAL-INSTITUTIONAL LEGACIES: CENTRAL-LOCAL TIES IN THE PHILIPPINES}

\subsection{A tradition of decentralized centralism}

The Philippines are often presented as a country with a longstanding tradition of centralism: "From the colonial Spanish regime to the recent Marcos era, the country has had a strong national government whose powers were concentrated at the centre." (Legaspi, 2001, p. 132). Notwithstanding modest efforts to devolve basic government functions after independence, under the postwar third republic (1946-1972), political-administrative centralism has indeed been the dominant form of political organization, and was taken to the extremes under the authoritarian Marcos martial law regime (1972-1981) (Wurfel, 1991).

Transcending the focus on the formal government structure, critical historical-institutional analysis has revealed how the country's peculiar experience with American colonialism 
during the first half of the twentieth century has fostered a significant degree of autonomy for local politicians (Hutchcroft, 2000). First, the Americans introduced democratic elections for local executive positions, and while temporarily suspended during martial law, this practice continues until this day (Franco, 2001). Furthermore, local elected officials were given extensive control over the police and military, which could be deployed for private political and economic gain (Hedman \& Sidel, 2000; Kreuzer, 2009). This localized control over the coercive state apparatus also persisted after independence and, at least in some areas, gave rise to what Sidel (1999) has described as "bossism": a highly coercive form of local politicaleconomic control whereby local politicians, often members of entrenched political dynasties, wield control in 'authoritarian enclaves' (Franco, 2001). For Abinales (2000), this prominent position of local politicians should be understood as part of a broader statebuilding agenda whereby local strongmen-politicians, in return for their local prerogatives, commit themselves to upholding the democratic electoral process, and to preventing the rise of organized opposition against the state -read: counterinsurgency (see also Wong, 2006).

At the same time there were clear limits to local autonomy, with Manila-based elites retaining control over their local counterparts through vertical patronage networks organized around the main political parties (Landé, 1968). Furthermore, when Ferdinand Marcos assumed the presidency in 1965, he gradually centralized control over the state security sector (Hedman \& Sidel, 2000), patronage resources (Hutchcroft, 1991), and the electoral process (Wurfel, 1991; Franco, 2001). This process of centralization culminated in martial law, which was proclaimed in 1972. However, while Marcos was fairly successful in reigning in selectively on local elites, the regime continued to rely on local powerbrokers for the implementation of its increasingly authoritarian development strategy. Ultimately, Marcos failed to do away with the localist tendencies in Philippine politics altogether (Hutchcroft, 2000). By the 1980s, the limits of the Marcos regime's debt-driven developmentalist strategy became apparent, and it was faced with mounting opposition from a broad range of societal forces, ranging from 
disenfranchised local elites to Muslim and communist insurgents that were particularly active in Mindanao (Abinales, 2000).

\subsection{Democratization and the Local Government Code}

The military mutiny and people power revolt that eventually overthrew Marcos and swept Corazon Aquino to power in 1986 ushered in an uncertain transition period, marked by a profound spirit of popular empowerment. The new 1987 constitution reflected this spirit, calling on congress to produce several pieces of legislation that would facilitate progressive social change. This included "a Local Government Code which shall provide for a more responsive and accountable local government structure instituted through a system of decentralization" (The 1987 constitution of the Republic of the Philippines, A. X, s. 3). While the Local Government Code was given high priority in congress, it would take until 1991 before it was eventually passed in the form of Republic Act (RA) 7160, which devolved important fiscal and regulatory responsibilities to local government units (LGUs; in descending order: the region, province, city, municipality and barangay (for a more detailed discussion see Legaspi, 2001; Yilmaz and Venugopal, 2013). Furthermore, LGUs became entitled to unconditional Internal Revenue Allotments (IRA) and a share of natural resource rents, which significantly decreased local politicians' financial dependence on national-level patrons (Clark, 1999). Finally, the code reestablished local executive control over the police.

So what motivated national-level politicians to cede substantial power and resources to local politicians? According to Eaton (2001), the answer lies in a combination of realpolitik on the part of congress members, and the extraordinary political circumstances of the transition period. Decentralization was first and foremost a product of the emancipatory spirit of people power, and President Aquino saw it as one of the defining legacies of her presidency (19861992). Meanwhile at least some members of congress, who were now bound by term limits, had ambitions to run for local office themselves one day, or at least had strategic allies (often 
family members) on the local level that would profit from a downward transfer of power and resources. Furthermore, national politicians managed to sneak in several safeguards in the Local Government Code that allowed them to retain at least some degree of control over their local-level counterparts (Eaton, 2001). For Siegle and O'Mahony (2006), decentralization was also a strategy to increase sociopolitical stability in the face of recurrent social conflict and rebellion. Two regions of the country that had experienced what was widely perceived as an ethnically motivated rebellion (the northern Cordilleras and the Muslim regions of Mindanao) during the Marcos years were placed under a special autonomy arrangement. However, even in those regions without such a special status, decentralization in the form of the Local Government Code can be seen as "a principal means to improve security by bringing government closer to the people" (Siegle and O'Mahony, 2006, p. 39). Significantly, in those areas of the peninsula with a significant rebel presence, the restoration of democratic state rule on the local level went hand in hand with brutal counterinsurgency efforts that involved vigilantes and paramilitary units supported by local (would-be) politicians (Van der Kroef, 1988; Hedman \& Sidel, 2000). As confirmed by field research findings, many of these vigilantes were later transformed into state-sanctioned security forces (Kreuzer, 2009) such as the Civilian Volunteer Organization (CVO), a supposedly unarmed barangay (village) level police force.

While decentralization was in large part a response to the authoritarian excesses of the Marcos regime, the Local Government Code was not a radical move away from a historically rooted centralism (Legaspi, 2001). Rather, based on this concise historical overview, it should be seen as a return to, and arguably a radicalization of, a longstanding tradition of decentralized statebuilding and counterinsurgency through local politicians (Hutchcroft, 2000; Wong, 2006). Indeed, critical observers were quick to point out that the 'democratic' transition soon turned out to be nothing more than a restoration of the elitist pre-Marcos institutional structure, including a return to traditional-style patronage- and coercion-based local politics (Hutchcroft \& Rocamora, 2003). Seen from this perspective, instead of resulting 
in increased participation or greater social equity, decentralization risked further entrenching local bosses (Hedman \& Sidel, 2000). This article seeks to build on -and hopefully qualifythese observations, through an empirical investigation of the impact of decentralization on the controversial domain of mineral resource governance where, as we will see, decentralization has unleashed a range of open-ended struggles over future institutional trajectories, and the associated distribution of mineral resource wealth.

\section{MINERAL RESOURCE GOVERNANCE IN AN ERA OF DECENTRALIZATION}

\subsection{The 1995 Mining Act as the centralist basis of mineral resource governance}

While Spanish colonialism (which lasted from the early $16^{\text {th }}$ century until 1898) failed to subjugate the entire peninsula, it did lay the basis for a highly centralized system of mineral resource governance centered around the Regalian doctrine, which vests ownership of public lands and all mineral resources in the (colonial) state. Notwithstanding a brief experiment with a freehold system under US rule, subsequent post-independence governments upheld this centralist spirit, which reached its climax during the Marcos years (Cabalda, Banaag, Tidalgo \& Garces, 2002). While under Marcos the mining sector was formally regulated through Presidential Decree 463, in reality it was governed by 'special deals' that benefited Marcos' intimate circle of cronies (Clad, 1988). Amidst mounting economic and political instability, the Marcos regime gradually lost control over the mining sector, which increasingly fell prey to mismanagement and corruption (Lopez, 1992). This corporate mining crisis was aggravated by a global commodity crisis in the 1980s, when a combination of increased mineral supply and decreasing demand, mainly due to the global economic downturn, led to a collapse of mineral prices (Maizels, 1992). Ultimately, many large-scale mining companies were forced to shut down their operations. As will be discussed in section 4.4, this large-scale mining crisis also provided the space for a dramatic expansion of small-scale gold mining. 
Subsequent governments in the post-Marcos era undertook a series of regulatory interventions aimed at reviving the fledgling mining sector. This eventually culminated, in 1995, in Republic Act No. 7942, "an act instituting a new system of mineral resources exploration, development, utilization and conservation". Better known as the 'Mining Act', RA 7942 upheld the centralist spirit of the Regalian Doctrine, by stating that "Mineral resources are owned by the State and the exploration, development, utilization, and processing thereof shall be under its full control and supervision. The State may directly undertake such activities or it may enter into mineral agreements with contractors." (Republic Act No. 7942, 1995: ch.I, s.2). The authority to administer and dispose of the state's mineral resource reserves was vested in the secretary of the Department of Environment and Natural Resources, and is effectively administered by the Mines and Geosciences Bureau (MGB), one of the line agencies of the Department of Environment and Natural Resourcess (DENR) (Ibid.: ch.II, s.8-9). The MGB now has several mineral-tenurial instruments at its disposal to issue mining rights, including Exploration Permits (EP), Financial Technical Assistance Agreements (FTAA), and Mineral Production Sharing Agreements (MPSA). With notable exceptions, including those areas covered by existing (small-scale) mining rights, mining rights can cover "all mineral resources in public or private lands" (Ibid.: ch.III, s.18).

In all, the Mining Act provided for a fairly clear-cut system of mineral resource governance, which centralized control over mineral resources in the hands of the national government. It aroused enthusiasm among (foreign) mining companies, and the number of mining applications increased dramatically over the following years and decades. As of January 31, 2014, there existed a total of 40 exploration permits covering 199,122 hectares, 339 MPSAs covering 602,012 hectares, and 6 FTAAs covering 108,872 hectares ${ }^{1}$.

\subsection{Decentralization and institutional ambiguities in mineral resource governance}

However, as noted by a long-time observer of the Philippine mining sector, the congressional deliberations that eventually produced the Mining Act were completely detached not only 
from realities on the ground, where small-scale mining had undergone a dramatic expansion; but also from a broader trend towards decentralization, spawned by a combination of shortterm political considerations and long-term concerns over democratization and security (Edwin Domingo, former assistant director of the Mines and Geosciences Bureau, personal communication, March 2, 2014). Significant for our purposes, this move towards decentralization also involved efforts to devolve control over mineral resources to a range of subnational actors.

First, the Local Government Code gave LGUs significant discretion over the issuance of permits and franchises, and over the enforcement of national environmental laws, stipulating that any project or program that "may cause pollution, climatic change, depletion of nonrenewable resources, loss of cropland, rangeland, or forest cover, and extinction of animal or plant species" requires the approval of affected LGUs (Republic Act No. 7160, s. 27-28). Furthermore, in addition to automatic Internal Revenue Allotments (IRA) from the national government, LGUs also became entitled to a share of 'resource rents' collected from activities involving the development of mineral resources within their territorial jurisdiction (Clark, 1999). Finally, LGUs were given control over small-scale mining (Republic Act No. 7160, s. 484).

Prior to 1991, artisanal and small-scale mining (ASM) was regulated by Presidential Decree 1899, a highly permissive permit system that was put in place by the Marcos government in 1984, allegedly to divert some of the ASM-gold into central bank coffers (anonymous respondent, personal communication, March 4, 2014; see also Clad, 1988). In line with the broader trend towards decentralization and democratization, in 1991 congress enacted Republic Act 7076, or the 'People's Small Scale Mining Act'. RA 7076 created provincial/city mining regulatory boards $(\mathrm{P} / \mathrm{CMRB})$ that were mandated to segregate $\mathrm{ASM}$-areas (Minahang Bayan) in public lands and to issue contracts inside these areas pending the consent of (potential) existing rights holders. Chaired by the MGB regional director, these mining regulatory boards are composed of representatives of respectively the local executive (the 
provincial governor or city mayor), small-scale mining, large-scale mining, and civil society. However, key informants from different provinces suggested that in practice these boards, if functional at all, are dominated by the local executive, who retains a high degree of discretion over the issuance of permits.

Finally, the same spirit of bottom-up empowerment eventually enabled the legislation of Republic Act 8371 ("an act to recognize, protect and promote the rights of indigenous cultural communities/indigenous peoples") in 1997 (Eder and McKenna, 2008). While the Indigenous People's Rights Act (IPRA) is not usually treated as an expression of decentralization, it nonetheless entails a radical devolution of rights over natural resources to indigenous communities. More specifically, the IPRA's main focus lies on the recognition of politicalterritorial ancestral domain rights that amount to (near-) complete property rights, formalized through Certificate of Ancestral Domain Titles (CADT) awarded by the National Commission on Indigenous Peoples (NCIP). Both the implementation and evaluation of the IPRA focus on the (hampered) process of Free and Prior Informed Consent (FPIC), whereby outsiders need to secure the explicit consent of the majority of the indigenous community in order to secure "any license, lease or permit for the exploitation of natural resources" (Republic Act No. 8371 , s. 46(a)), usually in exchange for some kind of royalty.

Significantly, these different laws co-exist uneasily not only with each other, but also with the centralist provisions of the 1995 Mining Act. According to the same observer cited earlier, "there were no real efforts to synchronize the Mining Act with the 'special laws'. We did not want to tackle the special laws, we trusted that local bodies would work out which law was appropriate (...) if necessary they can go back to old laws" (Edwin Domingo, personal communication, March 2, 2014). Together, this plethora of overlapping laws gives rise to a highly heterogeneous system of mineral resource governance, whereby different government levels and -agencies create contradictory and overlapping laws and administrative rules. In line with the analytical framework proposed in section two, this institutional ambiguity provides room for incremental institutional change, understood as the renegotiation of the 
institutional arrangements that distribute mineral resource wealth across society. This renegotiation of institutional arrangements is an intensely political process, that often produces conflicts on the ground. In order to substantiate this argument, and in order to make sense of current and future trajectories of institutional change, the remainder of this section provides an empirical analysis of the three major axes around which conflicts over the redistribution of mineral resource wealth are currently unfolding.

\subsection{Central-local government conflict over large-scale mining}

The first type of conflict that has surfaced at least in part due to decentralization are intragovernment conflicts over the expansion of large-scale mining. Increasingly, local politicians are using the provisions of the Local Government Code to oppose the entry of large-scale mining (Holden \& Jacobsen, 2006). While some LGUs have merely withheld consent for selected mining projects, others have gone further, implementing moratoria or even an outright ban on mining activities within their territory. The national government has in turn undertaken various efforts to counter LGU-opposition to mining projects. The latest of these efforts is executive order (EO) 79. Issued by president Aquino in 2012, EO 79 can partly be read as a response to increased anti-mining activism, as it calls for the strict enforcement of environmental standards, closes a number of areas for mining, and issues a ban on the issuance of new mineral agreements pending the passage of new legislation on revenue sharing (Salamat, 2012). At the same time EO 79 calls on LGUs to "confine themselves only to the imposition of reasonable limitations on mining activities" and "to conform to regulations, decisions and policies ... promulgated and taken by the National Government" (Executive Order No. 79, 2012, s. 12). In this way EO 79, and subsequent opinions and memorandums issued by national government officials that confirm the primacy of national government laws over local ordinances, can be seen as part of a broader attempt on the part of the current administration to recentralize control over mineral wealth. 
Undoubtedly the most widely cited case involving LGU-opposition to large-scale mining is that of the Tampakan open-pit copper-gold mining project in South Cotabato province, which is co-owned by Filipino Sagittarius Mining (SMI) and Swiss mining giant Glencore-Xstrata. On June 29, 2010, South Cotabato provincial Governor Fuentes signed into law a provincial environmental code that banned the use of open-pit mining methods (Aquiles, 2010). However, in February 2013, following an order by the MICC (the national coordinating council for the mining sector created by virtue of Executive Order 79), the Department of Environment and Natural Resources decided to grant the company its environmental compliance certificate, thus neglecting the provincial environmental code ("Finally, Tampakan", 2013). Rather than fast-tracking the Tampakan project, however, the DENR's move is indicative of a near-complete gridlock between the national government and LGUs. Meanwhile a combination of a deteriorating security situation (in recent years Tampakan has witnessed a parallel increase in illegal hydraulic mining and communist rebel activity), increased anti-mining activism (particularly on the part of the church), and last but not least LGU-opposition, has led to repeated delays in the progress of the Tampakan project. There are now important indications that Swiss Glencore-Xstrata is planning to divest its majority share in the Tampakan project, with the company citing the legal uncertainty created by the provincial ordinance as one of its key motivations (Espejo, 2014).

The Tampakan case illustrates how local politicians emboldened by decentralization have become key gatekeepers in the large-scale mining sector. However, important questions remain with regards to their motivation to resist the expansion of large-scale mining. For Holden and Jacobsen (2006), this opposition stems from an interplay between civil society activism, a growing awareness about the environmental impacts of mining, and politicalelectoral considerations on the part of local politicians. However, countless LGU-officials indicated that they are not necessarily opposed to large-scale mining as such. Rather, they are fed up with what they perceive as a top-down decision process: "Whatever the MGB says, we are expected to comply. And whenever something goes wrong, guess who takes 
the blame?" (municipal government official in Compostela Valley, personal communication, October 12, 2012). More importantly, numerous local government treasurers expressed frustration over the lack of fiscal benefits associated with large-scale mining. Under the Local Government Code, LGUs are entitled to a 40 percent share of previous year's collection of excise tax from mining activities within their territorial jurisdiction (Clark, 1999). However, both the collection and redistribution of tax revenues are mired in problems (Gomez, 2010). The overall tax effort in mining is low compared to that in other sectors, not least because of a range of fiscal stimuli introduced to encourage investment in the mining industry. Furthermore, it has proven an arduous task for the relevant government agencies to correctly estimate output levels in large-scale mining, and consequently to collect accurate amounts of excise tax. Ultimately, LGU-officials complain about what they perceived as mere "handouts", about long delays in the "downloading" of LGU-shares, and about the notoriously intransparant nature of revenue sharing (provincial treasurer of Compostela Valley, personal communication, October 12, 2012).

\subsection{Small-scale mining versus large-scale mining in Compostela Valley province}

A second type of conflict, which has become entangled in complex ways with that between the national government and LGUs, is that between large-scale mining and artisanal and small-scale mining (ASM). Despite its sheer size, the ASM-sector remains largely absent in broader societal debates about mining in the Philippines. Instead these debates focus onesidedly on large-scale mining. As will be illustrated in this section, the presence of ASM may in fact be a factor in its own right fuelling local resistance to large-scale mining.

Since the 1980s Compostela Valley province ${ }^{2}$ in southeastern Mindanao, the self-proclaimed "gold mining capital of the Philippines", has witnessed a massive expansion of ASM. By and large this expansion has taken place beyond the formal-regulatory control of the national government, which consequently brands these ASM-activities as illegal. As indicated earlier, in 1984 the Marcos government undertook a first unsuccessful effort to bring ASM under 
national government control, in the form of presidential decree 1899. Likewise, Republic Act 7076 (the 'People's Small Scale Mining Act') of 1991 turned out to be rather unsuccessful as an instrument for ASM-formalization, with only a very limited number of ASM-operations now taking place inside Minahang Bayan that have been approved as such by the secretary of the Department of Environment and Natural Resources. This failure of existing formalization efforts has various causes, including complex and costly registration procedures, and nepotism and rent-seeking during the allocation of permits. Arguably more important is that ASM often takes place inside large-scale mining concessions, without the official consent of the rights-wielding company. This issue of 'illegality' became more pronounced in 2011, when the government imposed new taxes on gold sales. While the central bank still retains a legal monopoly on gold buying, most ASM-gold is now diverted through clandestine trading networks (Francisco, 2012).

These observations feed into allegations on the part of ASM-operators that existing regulatory frameworks favor large-scale, corporate mining. As one financier described the current situation: "For us it is like climbing Mount Everest, while for them, they can come in and slide down the mountain. The paramilitaries are part of the package deal." (barangay official and mining financier, personal communication, January 27, 2014). Executive Order 79 was interpreted as the latest illustration of this government bias against ASM, as it seeks to "contain" it in officially recognized Minahang Bayan, and calls for the creation of a "Task Force Against Illegal Mining" (Executive Order No. 79, s. 10, s. 11). In addition, mining companies are calling on the MGB to issue stoppage orders to ASM operating inside their concession, and are calling in the assistance from local governments, the police, or in some cases even the military to implement these orders.

At least in the case of Compostela Valley province, however, attempts to root out ASM have so far proven unsuccesful. Here, images of an all-powerful alliance between 'the government' and corporate mining capital, united in their struggle to root out illegal ASM, fail to do justice 
to how the sector has become embedded in the local institutional fabric, and has become intimately entangled with local political interests.

\subsubsection{Local politics and the 'illegal' mining economy}

The initial expansion of small-scale gold mining in the 1980s took place at a highly volatile time in the history of eastern Mindanao, which was a stronghold of the communist insurgency of the New People's Army. Elements from the different armed groups roaming the region developed a keen interest in the ASM-sector, which was soon controlled by indistinct militarycommercial networks comprised of police officers, army commanders and -intelligence officers, communist rebels and mining financiers (Verbrugge, 2014). Since democratization and decentralization in the early 1990s, some of these actors became involved in the local electoral arena, leading to the emergence of a group of 'miner-politicians' that cultivate intimate connections with ASM-financiers and with the various armed actors operating in the region, some of which were later recruited into the "private armed groups" (Kreuzer, 2009) of miner-politicians. Over time distinctions between these private armed groups and statesanctioned armed actors such as the Civilian Volunteers Organization, a barangay-level police force, and the Citizen Armed Force Geographical Unit, an irregular auxiliary force of the AFP, have gradually faded. Slowly but surely, local politicians emerged at the center of "peculiar coercive arrangements" (Hedman \& Sidel, 2000) that provided them with the coercive leverage necessary to expand their personal, fiscal and regulatory control over the purportedly 'illegal' mining economy.

The mutual entanglement between ASM and local politicians is particularly evident on the level of the barangay, the lowest government level. In addition to high degrees of personal involvement in ASM on their part, barangay officials have also developed inventive ways to extract rents from ASM. More importantly, in several mining areas they are now undertaking a range of more sophisticated fiscal and administrative interventions in ASM, including the registration of tunneling agreements between mining financiers and (informal) landowners, 
mediation in disputes between tunnel- and/or landowners, and the issuance of business permits to owners of processing facilities. By the late 2000s, in response to a renewed gold rush, provincial authorities have even put up a system of checkpoints for the collection of "environmental user's fees" and "donations". Significantly, while the national government continues to brand the mining activities in question as illegal, most of the fiscal-administrative interventions in question have a legal basis in the Local Government Code, and are described in the amended local revenue code of the province.

In recent years provincial authorities have taken this regulatory drive one step further, using existing regulatory frameworks for ASM to initiate a bottom-up process of formalization. After the provincial mining regulatory board (PMRB) -which effectively operates at the behest of the provincial governor- has identified an ASM-area, it will file a formal request in the regional MGB-office for the technical and commercial evaluation of the area as Minahang Bayan (staff of Provincial Agriculturalist Office of Compostela Valley, personal communication, January 18, 2014). According to MGB-officials, ASM-operators will often present them documents and tax receipts issued by LGUs to underpin their claims to the area in question. However, since most ASM takes place inside large-scale mining concessions, even if the area receives a positive technical and commercial evaluation, the company will not be willing to consent to the regularization of ASM inside its claim. Hence, the areas in question are now categorized as "proposed Minahang Bayan". A provincial government official told the author that the province is now considering an ordinance that would enable the official recognition, at least on the level of the province, of Minahang Bayan inside large-scale mining concessions without the consent of the company, provided that the company "maintains no visible presence on the ground" (Ibid.). Large-scale mining companies, on their part, continue to approach the MGB to issue stoppage orders against illegal ASM, which are then delivered by local government officials, a representative of the Department of Environment and Natural Resources and/or by a delegation of state security personnel. So far however, these stoppage orders have proven futile, in large part, a mining 
company representative claimed, because "Those delivering the stoppage orders are actually those controlling the small-scale mining. They will take a picture standing next to the closed tunnel, and one week later it is operating again" (community relations officer of largescale mining company, personal communication, January 18, 2014).

So far, this section has drawn attention to how local politicians have taken center stage in the indistinct politico-military-commercial networks that reign over ASM. These same politicians are making inventive use of their mandate under decentralization to undertake a series of fiscal-administrative interventions in the purportedly "illegal" mining economy, thus contesting the terms of legality itself. What is classified as "illegal" and "illegitimate" by national government actors, may in fact be the outcome of an exclusionary legal framework, and may be considered perfectly legitimate on the local level (Lahiri-Dutt, 2007). In fact, several smallscale mine operators did not have the slightest idea about national regulatory frameworks, and consider their operations as legal because they were sanctioned by local government officials. Based on the analytical framework proposed in section two, it could therefore be argued that local miner-politicians have emerged as agents of incremental institutional change, capitalizing on the institutional ambiguities produced by decentralization to tilt the institutional balance in favor of ASM. Meanwhile on the ground, these institutional struggles stand in constant interaction with real-life conflicts over access to mineral-yielding land, which involve indistinct coalitions of actors connected with small-scale and/or large-scale mining interests.

\subsubsection{Conflicts over access to mineral wealth ${ }^{3}$}

The most (in)famous example is that of Diwalwal in Monkayo, where pre-existing tensions between competing ASM-groups composed of mining financiers and armed actors such as army intelligence officers, police officers, and (former) communist rebels escalated into a fullblown underground war in the 1990s, when a large-scale mining company decided to side with one of these groups (JB mining) in an attempt to gain control over the gold-rich area 
(Gonzales \& Conde, 2002). By the early 2000s, the conflict had spilled over into the politicalelectoral arena. On the one hand barangay authorities, personified by the charismatic barangay captain Franco Tito, had a clear interest in ASM, not merely on a personal level but also as a source of fiscal revenues and as a platform to assert their authority. Meanwhile municipal mayor Joel Brillantes was a former army intelligence officer who had become engaged in ASM as the strongman of JB mining, but had now joined the ranks of large-scale mining. In response to the unrest in Diwalwal and surrounding areas, in 2002 president Gloria Macapagal-Arroyo proclaimed a 8100 hectare 'Diwalwal mineral reservation' that would be controlled by the Natural Resources Mining Development Corporation (NRMDC), the "corporate arm of the DENR" (Bagayaua, 2008). However, the government takeover and the subsequent militarization of the area failed to defuse tensions. Instead, municipal mayor Brillantes was using his mayoral prerogatives and allegedly also his contacts in the army to protect his own mining interests and to harass his ASM-foes. Meanwhile it is a public secret that the communist New People's Army continues to profit handsomely from ASM in the form of revolutionary taxes (this was also confirmed by an International Crisis Group report, see ICG, 2011). Hence, the Diwalwal conflict intertwines in complex ways with the broader conflict between the army and the NPA. Mounting tensions and a spate of underground killings eventually culminated in the murder of mayor Brillantes in June 2003 ("Compostela Mayor", 2003). In 2008, the government unveiled a new plan for the mineral reservation, which would be subdivided in 3 zones (Bagayaua, 2008): a "Tribal Mining Area" (TMA, see section 4.5), "Mining Investment Areas"4, and the Diwalwal gold rush area itself, which was placed under a very complex arrangement that ultimately failed to alleviate ASM's concerns over large-scale mining expansion. In recent years, tensions in and around the mineral reservation are again on the rise. While the national government is beefing up the presence of the army, purportedly to protect local communities from 'extortionist' communist rebels, ASM and leftist activists decry the militarization of Diwalwal, claiming that the army is only there to facilitate a take-over by multinational mining interests (these claims surfaced during various interviews, but see also "Army deploys", 2010). 
A second example is that of New Bataan, where, in the mid-2000s, PHILCO mining was confronted with a sudden expansion of ASM inside its exploration claim. PHILCO responded by beefing up its security forces, and by securing stoppage orders from the MGB regional office in Davao City. These orders were delivered to ASM-operators by delegations of DENR-staff, municipal and barangay officials, police, and in one instance even army personnel. Rather than leading to a stoppage of ASM, however, indistinct elements affiliated with ASM and according to some also with the communist NPA, started harassing (and in one instance killing) PHILCO-guards, and repeatedly torched the company's equipment. The situation became even more complicated in the late 2000s, when ASM-operators with the support of politicians at the municipal and provincial level, organized themselves into an association, and applied for the segregation of a "Minahang Camanlangan" (named after the barangay hosting the mining area). By the time of the last visit to the area, ASM was still in firm control. And while PHILCO had effectively transferred its rights to two other mining companies, Batoto resources and Agusan Metals Corporation, these companies did not have a significant presence in the area, and the few remaining employees -ironically mostly local landowners that were collecting royalties from ASM themselves- admitted that it was very difficult if not impossible for the company to operate in the area.

\subsubsection{Towards a win-win solution?}

Ultimately, the current situation in Compostela Valley is best described as a "strategic stalemate". On the one hand, large-scale mining concessionaires wielding formal mining rights are having a hard time to effectively exercise these rights due to the persistence of ASM. On the other hand, ASM-operators now see their mining rights recognized in local institutional arrangements, but face a range of obstacles -not least the overlap with largescale mining- that prevent the official recognition of these rights on the national government level. 
Nearly all of the actors involved -except (most) large-scale mining companies- now recognize the need to move towards a win-win solution. Even MGB-officials in the Davao City regional office were not entirely unsympathetic to the idea of working out a solution that is acceptable both for ASM and for large-scale mining, mainly because: "It is our job to promote mining (...) but now there are too many companies that are just speculating, just holding on to their claim as a future asset (...) this is our problem now" (staff in MGB-regional office in Davao City, personal communication, January 24, 2014). However, important questions remain with regards to the willingness of large-scale mining to move towards such a win-win solution, and with regards to who would eventually benefit from such a solution. Initial observations suggest that corporate actors are now realigning, identifying local agents that can help tilt the institutional balance in their favor. Based on the preceding analysis, it should not come as a complete surprise that local politicians form one of their key targets, and several politicians previously sympathetic towards ASM have now openly aired their support for large-scale mining. Particularly in recent years, another important institutional player has entered the scene, namely tribal groups claiming priority rights over mineral resources and associated royalties under the Indigenous Peoples Rights Act.

\subsection{The IPRA, the mining sector, and tribal conflicts}

The legislation of the Indigenous Peoples Rights Act (IPRA) in 1997 aroused significant opposition, not least on the part of the Philippine Chamber of Mines and the MGB, who argued that granting indigenous communities priority rights over their ancestral domain and over the (mineral) resources underlying it violated the constitutionally enshrined principle of state ownership of public lands and minerals (Eder \& Mckenna, 2008). Others have drawn attention to the hampered implementation of the IPRA, and how it fits in with a broader trend towards the dispossession of indigenous communities by mining companies (Holden, Nadeau \& Jacobsen, 2011). This section, like the previous one, seeks to qualify this dominant analytical focus on dispossession from above, by means of an admittedly initial 
discussion of tribal conflicts over mineral wealth unleashed by the IPRA, which can be seen as yet another illustration of the spirit of decentralization (see section 4.2).

\subsubsection{The ahistorical IPRA and indigenous 'communities'}

To understand the impact of the IPRA on local institutional arrangements, we first need to critically evaluate its definition of Indigenous Peoples as "historically differentiated from the majority of Filipinos" (Republic Act No. 8371, 1997: s. 3(h)). By invoking an image of isolation and uniqueness, this definition obscures a long history of interaction between upland pagans and Christian lowlanders, which resulted in a serious distortion of traditional indigenous structures -a notoriously indistinct concept to begin with. Even prior to the IPRA, the Philippine state undertook various efforts to deal with the upland population, including the creation of different special bodies, agencies and programs (Eder \& McKenna, 2008). Meanwhile increased upland migration on the part of non-indigenous settlers, combined with processes of economic modernization, resulted in processes of social differentiation across the indigenous / non-indigenous divide (Dressler \& Turner, 2008). Particularly (but not exclusively) in Mindanao, parts of the upland population were also recruited for insurgency or counterinsurgency purposes, spurring further divisions in upland communities (Asia Watch Committee, 1992).

Last but not least, the proliferation of political-administrative (barangay-, municipal, provincial and regional) boundaries that cross-cut the ancestral domain had a profound impact on indigenous authority structures. Particularly following democratization and decentralization in the early 1990s, many datus (the local term for a traditional leader) became directly (as candidates) or indirectly (as vote brokers) involved in political-electoral competition; a trend that was, somewhat paradoxically, encouraged by the National Commission of Indigenous Peoples when it called for the mandatory representation of indigenous peoples in local legislative councils in 2009 (NCIP administrative order No. 001, s. 2009). As confirmed by various key respondents, this created opportunities for local politicians to expand their 
patronage networks into the indigenous community; and for educated, rich, or "brave" tribals to assert themselves as datus.

Ultimately, when NCIP-staff are talking about "organizing a community" (i.e. identifying its leaders and delineating its ancestral domain), they are dealing with an upland population divided along the lines of class, clan affiliation, the insurgency-counterinsurgency divide, and last but not least dynamic political-electoral alliances. Given these cross-cutting cleavages, it should not come as a complete surprise that the entry of mining and associated royalties entails risks for conflict.

\subsubsection{Mining royalties and tribal conflicts in Compostela Valley province ${ }^{5}$}

Gold-rich Diwalwal can again serve as a good empirical illustration. After the enactment of the IPRA in 1997, different datus claiming to represent the Mandaya, Mansaka, Dibabawon and Manguanggan tribes, started filing overlapping ancestral domain claims over the area that contained the Diwalwal gold rush area. These competing tribal groups were connected with the different mining groups that were fighting over Diwalwal's rich gold deposits, and that included not only armed actors but also miner-politicians (Canuday, 2008; see section 4.4). The subsequent nationalization of Diwalwal in 2002 went hand in hand with an effort to pacify the indigenous community. In close coordination with the different tribal groups, the NCIP started working towards a reunification effort, eventually resulting in the issuance of Certificate of Ancestral Domain Title 0702-0007 to the 'four tribes of Monkayo' (Canuday, 2008). However, while the indigenous problem was now legally settled, by no means did this solution end in-fighting within the tribal community. Things even got worse after the creation, in 2008, of the tribal mining areas (TMA): those parts of the Diwalwal mineral reservation wherein the four tribes of Monkayo could exercise their priority rights. After the four tribes had entered into a joint venture with the Philippine Mining Development Corporation and started looking for investors, different tribal leaders signed agreements -allegedly "in exchange for a signing bonus of millions" (tribal leader from Monkayo, personal 
communication, 12 February 2012)- that covered overlapping areas. The resulting competition led to a spate of killings in the tribal community that continues until this day (“Mining Firm", 2011).

A second example is that of Maco, where royalties from APEX mining -currently the only large-scale mining company in Compostela Valley province that is currently in the production stage- are sowing discord in the Mansaka tribe. In 2003, the NCIP provincial office supported the formation of an association that convened indigenous land claimants from the different "impact barangays", i.e. those barangays directly affected by the APEX-operations. This association, SIMI, was dominated by the Onlos clan, which was headed by a certain datu Onlos. In 2008, after the Mansaka tribe was issued its CADT, APEX started paying royalties to both SIMI and $\mathrm{MDCl}$, another organization controlled by Datu Onlos that was set up as a vehicle for the redistribution of APEX-royalties over 29 barangays that have a Mansaka mandatory representative. In 2010, however, datu Onlos was killed, and soon after this a new organization was created with the assistance of NCIP, APEX and last but not least local politicians. While this new organization, MIPADMA, also absorbed several MDCImembers, others were sidelined, and there are now several barangays with both MDCl- and MIPADMA-aligned datus, with the latter now on the receiving end of the royalty sharing. As in the Diwalwal case, electoral politics played a key role in sowing discord in the tribal community. 2010, the year of datu Onlos' killing and of MIPADMA's creation, was an important election year, and many MIPADMA-members became acting mandatory tribal representatives on the barangay- or municipal level; or at least have a clear affiliation with local politicians. Also telling in this regard is the ongoing construction (in February 2014) of an 11 million peso (around US\$250000) tribal hall, next to the municipal hall.

To be sure, these tribal conflicts over ancestral domain rights and associated royalties are embedded in a broader and much more complex conflict ecology. However, both in Maco and in Monkayo the situation at the time of the research was too volatile and sensitive to get to the heart of the matter without jeopardizing the security of the researcher or, more 
importantly, that of his respondents; and there was a general reluctance to discuss many of the issues at hand. Some tentative and more general observations can nonetheless be made. First, these tribal conflicts stand in close connection with political-electoral competition, and initial evidence suggests that -in line with the situation in countries such as Ethiopia (Hagman \& Mulugeta, 2008) and neighboring Indonesia (Schulte Nordholt \& van Klinken, 2007), the decentralization of resources on the basis of ethnicity fosters the growth of patronage networks that convene local politicians and 'ethnic entrepreneurs'. Secondly, because several (self-proclaimed) tribal leaders have a longstanding involvement in ASM, these tribal conflicts also intertwine with the conflict between ASM and large-scale mining described in section 4.4. For example, the late datu Onlos was known to be involved in ASM, and was a staunch opponent of the further expansion of large-scale mining in Maco ("Auction of Davao", 2009). Thirdly, these tribal conflicts interact in complex ways with the broader conflict between the Philippine government and the communist NPA. As one datu from Monkayo stated: "Every tribe has its own security strategy (...) some join the counterinsurgency of the AFP (...) if you don't join you get killed because they say you are a communist" (IP-leader from Monkayo, personal communication, February 2012).

\section{CONCLUDING REMARKS}

In the first instance this article has aimed to make a contribution to broader debates on the relationship between decentralization and conflict. It did so by proposing a conceptualanalytical framework that draws central attention to the ways in which decentralization offers opportunities for incremental institutional change, understood as a renegotiation of the ways in which power and resources are distributed across society. Such a renegotiation of institutional arrangements is a political process par excellence, and often goes hand in hand with conflicts on the ground. 
The added value of this analytical approach was illustrated on the basis of the situation in the Philippine mining sector, producing a second set of more context-specific arguments. Various legislative efforts to decentralize control over mineral resource wealth to subnational actors co-exist uneasily with the centralist provisions of the Philippine Mining Act, purportedly still the basis of mineral resource governance in the country. This has given rise to a highly heterogeneous and ambiguous institutional arena, wherein a broad array of actors are now contesting the redistribution of mineral resource wealth. In an attempt to make sense of these complex institutional struggles, three major cleavages were identified around which mineral resource conflicts are now crystallizing, namely intra-government conflicts over fiscal-regulatory authority in the mining sector, conflicts between small-scale- and large-scale mining over access to mineral-yielding land, and conflicts between tribal groups seeking to secure ancestral domain rights and associated royalties. Hence, rather than increasing sociopolitical stability, seemingly uncoordinated efforts to decentralize mineral resource governance have increased local mineral resource conflicts, by enabling a broad range of actors to stake competing claims to mineral wealth.

To be sure, the outcomes of these conflicts over institutional arrangements -which are increasingly producing violent confrontations on the ground- are not necessarily negative. Instead they may produce substantial emancipatory effects in the form of a redistribution of mineral resource rents to a greater number of people. In line with the new "localist paradigm" in natural resource management (Arellano-Yanguas, 2011), many would consider increased local control over resources -whether in the hands of small-scale miners or indigenous communities- to be a good thing. However, while decentralization may indeed have offered opportunities for the redistribution of resource wealth in favor of selected local actors, two worrying trends are gradually becoming apparent.

First, partly as a product of ongoing decentralization efforts, but also as a legacy of a longer history of decentralized statebuilding, local politicians now play a key role in existing institutional arrangements, and will likely continue to do so in the future. In line with concerns 
raised by critical observers of decentralization in other countries, this raises important concerns over elite capture. These concerns are particularly pressing when considering a second trend, namely the gradual (re)concentration of control over mineral resource wealth. On the one hand, mining companies are slowly adjusting their strategies to local institutional realities by identifying key actors - particularly local politicians and tribal leaders- that can help tilt the institutional balance in their favor. On the other hand -and this is an issue that has not been dealt with in depth in this article- there is a parallel trend towards the professionalization and capitalization of ASM under the tutelage of a heterogeneous group of 'capital interests', composed of mining financiers, royalty-receiving landowners, armed rentseekers and, last but not least, local miner-politicians (Verbrugge, 2014). On the losing end of this equation is a massive labor force that is increasingly bereft of meaningful access to mineral resource wealth ${ }^{6}$.

\section{REFERENCES}

Abinales, P. N. (2000). Making Mindanao: Cotabato and Davao in the Formation of the Philippine Nation-State. Manila: Ateneo de Manila University Press.

Andersson, K. P., Gibson, C. C., \& Lehoucq, F. (2006). Municipal politics and forest governance: Comparative analysis of decentralization in Bolivia and Guatemala. World Development, 34(3), 576-595.

Aquiles, Z. (2010). South Cotabato governor signs ban on open-pit mining. Retrieved from http://www.inquirer.net/specialreports/theenvironmentreport/view.php?db=1\&article=201 00629-278231.

"Army deploys more troops to Compostela Valley" (2010). Retrieved from http://www.sunstar.com.ph/davao/army-deploys-more-troops-compostela-valley 
Arellano-Yanguas, J. (2011). Aggravating the resource curse: decentralisation, mining and conflict in Peru. The Journal of Development Studies, 47(4), 617-638.

"Auction of Davao mining project stopped by indigenous groups" (2009). Retrieved from http://www.minesandcommunities.org/article.php?a=9508.

Asia Watch Committee (US) (1992). Bad Blood: Militia Abuses in Mindanao, the Philippines. Washington: Human Rights Watch.

Bagayaua, Gemma. 2008. Divide and Rule. Newsbreak, July/September 2008, 58-61.

Bakke, K. M., \& Wibbels, E. (2006). Diversity, disparity, and civil conflict in federal states. World Politics, 59(1), 1-50.

Batterbury, S. P., \& Fernando, J. L. (2006). Rescaling governance and the impacts of political and environmental decentralization: an introduction. World Development, 34(11), 1851-1863.

Béné, C., Belal, E., Baba, M. O., Ovie, S., Raji, A., Malasha, I., Friday, N., Manane, N., Russel, A. \& Neiland, A. (2009). Power struggle, dispute and alliance over local resources: analyzing 'democratic'decentralization of natural resources through the lenses of Africa inland fisheries. World Development, 37(12), 1935-1950.

Benjamin, C. E. (2008). Legal pluralism and decentralization: Natural resource management in Mali. World Development, 36(11), 2255-2276.

Boone, C. (2003). Decentralization as political strategy in West Africa. Comparative Political Studies, 36(4), 355-380.

Brancati, D. (2008). Peace by Design: Managing Intrastate Conflict through Decentralization. Oxford: Oxford University Press. 
Cabalda, M. V, Banaag, M. A., Tidalgo, P. N. T., \& Garces, R. B. (2002). Sustainable Development in The Philippine Minerals Industry : A Baseline Study. London: International Institute for Environment and Development.

Canuday, J. (2008). Diwalwal case: The rise of Lumad capitalists. Unpublished manuscript. Davao City: Ateneo de Davao University.

Clad, J. (1988). Exploring for Policies. Far Eastern Economic Review, 142(43), 76-77.

Clark, A. L. (1999). Government Decentralization and Resource Rent Revenue Sharing: Issues and Policy. Occasional papers - economic series, number 1. Honolulu: EastWest Center.

"Compostela Mayor third to be killed in a week". The Philippine Daily Inquirer. 30 June 2003. A1, A18.

Dressler, W. and Turner, S. (2008). The Persistence of Social Differentiation in the Philippine Uplands. Journal of Development Studies, 44(10), 1450-1473.

Eder, J. F. \& McKenna, T. M. (2008). Minorities in the Philippines: Ancestral Lands and Autonomy in Theory and in Practice. In Duncan, C. R. (Ed.), Civilizing the margins: Southeast Asian government policies for the development of minorities (56-85). Singapore: NUS Press.

Eaton, K. (2001). Political Obstacles to Decentralization: Evidence from Argentina and the Philippines. Development and Change, 32(1), 101-127.

Eaton, K. (2006). The Downside of Decentralization: Armed Clientelism in Colombia. Security Studies, 15(4), 533-562.

Eilenberg, M. (2009). Negotiating autonomy at the margins of the state: The dynamics of elite politics in the borderland of West Kalimantan, Indonesia. South East Asia Research, 17(2), 201-227. 
Espejo, E. (2014). Low metal prices, uncertainties stall Tampakan operation. Retrieved from http://www.rappler.com/business/special-report/whymining/whymining-lateststories/54123-low-metal-prices-uncertainties-stall-smi-tampakan-operation.

Executive Order No. 79 (2012). Retrieved from http://www.gov.ph/2012/07/06/executiveorder-no-79-s-2012/.

Faguet, J. P. (2014). Decentralization and governance. World Development, 53(1), 2-13.

"Finally, Tampakan mine environmental clearance okayed" (2013). Retrieved from http://www.rappler.com/business/special-report/whymining/whymining-lateststories/22108-finally,-tampakan-mine-environmental-clearance-okayed.

Francisco, R. (2012). Special Report: Philippines' black market is China's golden connection. Retrieved from http://www.reuters.com/article/2012/08/23/us-philippines-goldidUSBRE87M02120120823

Franco, J. C. (2001). Elections and Democratization in the Philippines. New York: Routledge.

Gomez, M. (2010). Transparency Issues in the Philippine Mining Industry - Towards Tax Justice. Quezon City: Action for Economic Reforms.

Gonzales, D. and Conde, C. H. (2002). Entry of Huge Mining Firm Turns Diwalwal into Powder Keg. Retrieved from http://bulatlat.com/news/2-30/2-30-caloy2.html.

Hadiz, V. R. (2004). Decentralization and Democracy in Indonesia: A Critique of NeoInstitutionalist Perspectives. Development and Change, 35(4), 697-718.

Hagmann, T., \& Mulugeta, A. (2008). Pastoral conflicts and state-building in the Ethiopian lowlands. Africa Spectrum, 43(1), 19-37.

Hedman, E-L., \& Sidel, J. T. (2000). Philippine Politics and Society in the Twentieth Century Colonial legacies, post-colonial trajectories. London: Routledge. 
Heemskerk, M. (2005). Collecting data in artisanal and small-scale mining communities : Measuring progress towards more sustainable livelihoods. Natural Resources Forum, 29, 82-87.

Holden, W. N., \& Jacobson, R. D. (2006). Mining amid decentralization. Local governments and mining in the Philippines. Natural Resources Forum, 30, 188-198.

Holden, W., Nadeau, K. \& Jacobsen, R. D. (2011): Exemplifying accumulation by dispossession: mining and indigenous peoples in the Philippines. Geografiska Annaler: Series B, Human Geography, 93(2): 141-61.

Hutchcroft, P. D. (1991). Oligarchs and Cronies in the Philippine State: The Politics of Patrimonial Plunder. World Politics, 43(3), 414-450.

Hutchcroft, P. D. (2000). Colonial masters, national politicos, and provincial lords: central authority and local autonomy in the American Philippines, 1900-1913. The Journal of Asian Studies, 59(2), 277-306.

Hutchcroft, P. D., \& Rocamora, J. (2003). Strong Demands and Weak Institutions: The Origins and Evolution of the Democratic Deficit in the Philippines. Journal of East Asian Studies, 3, 259-292.

ICG - International Crisis Group (2011). THE COMMUNIST INSURGENCY IN THE PHILIPPINES: TACTICS AND TALKS. Asia Report N²02. Brussels: International Crisis Group.

Kreuzer, P. (2009). Private Political Violence and Boss-Rule in the Philippines. Behemoth, 2(1), 47-63.

Kymlicka, W. (1998). Is Federalism a Viable Alternative to Secessionism? In Lehning, P.B. (Ed.), Theories of Secessionism (111-150). New York: Routledge Press. 
Lahiri-dutt, K. (2007). Illegal coal Mining in Eastern India: rethinking legitimacy and limits of Justice, 42, 57-66.

Landé, C. H. (1968). Parties and Politics in the Philippines. Asian Survey, 8(9), 725-747.

Larson, A., \& Ribot, J. (2004). Democratic decentralisation through a natural resource lens: an introduction. The European Journal of Development Research, 16(1), 1-25.

Legaspi, P. E. (2001). THE CHANGING ROLE OF LOCAL GOVERNMENT UNDER A DECENTRALIZED STATE: The case of the Philippines. Public Management Review, 3(1), 131-139.

Lijphart, A. (1977). Democracy in plural societies: A comparative exploration. Yale: Yale University Press.

Locke, C., \& Lloyd-Sherlock, P. (2011). Qualitative life course methodologies: critical reflections from development studies. Development and change, 42(5), 1131-152.

Lopez, S. (1992). Isles of Gold: A history of Mining in the Philippines. Oxford: Oxford University Press.

Maconachie, R. (2010). "NEW SPACES" FOR CHANGE?: DIAMOND GOVERNANCE REFORMS AND THE MICRO-POLITICS OF PARTICIPATION IN POST-WAR SIERRA LEONE. Public Administration and Development, 30(3), 191-202.

Mahoney, J. (2010). Colonialism and postcolonial development: Spanish America in comparative perspective. Cambridge: Cambridge University Press.

Mahoney, J., \& Thelen, K. (2009). Explaining institutional change: ambiguity, agency, and power. Cambridge: Cambridge University Press.

Maizels, A. (1992). Commodities in Crisis: The Commodity Crisis of the 1980s and the Political Economy of International Commodity Policies. Oxford: Oxford University Press. 
Marks, T. A. (1996). Maoist insurgency since Vietnam. Psychology Press.

Mccarthy, J. F. (2004). Changing to Gray: Decentralization and the Emergence of Volatile Socio-Legal Configurations in Central Kalimantan, Indonesia. World Development, 32(7), 1199-1223.

"Mining firm gains tribes' support to explore Mt. Diwata". (2011) Retrieved from http://www.interaksyon.com/article/7137/mining-firm-gains-tribes-support-to-explore-mt-diwata

NCIP administrative order No. 001, series of 2009 (2009). Retrieved from http://law.upd.edu.ph/index.php?option=com_docman\&task=cat_view\&gid=154\&ltemid= 242.

Pattenden, J. (2011). Gatekeeping as Accumulation and Domination: Decentralization and Class Relations in Rural South India. Journal of Agrarian Change, 11(2), 164-194.

Peluso, N. L. (2007). Violence, Decentralization, and Resource Access in Indonesia. Peace Review: A Journal of Social Justice, 19(1), 23-32.

Pierson, P. (2004). Politics in time: History, institutions, and social analysis. Princeton: Princeton University Press.

Poteete, A. R., \& Ribot, J. C. (2011). Repertoires of domination: Decentralization as process in Botswana and Senegal. World Development,39(3), 439-449.

Pulhin, J. M., \& Dressler, W. H. (2009). People, power and timber: the politics of communitybased forest management. Journal of Environmental Management, 91(1), 206-14.

Ravikumar, A., Andersson, K., \& Larson, A. M. (2013). Decentralization and forest-related conflicts in Latin America. Forest Policy and Economics, 33, 80-86. 
Republic Act No. 7076: The People's Small-Scale Mining Act of 1991. Retrieved from http://mgb.gov.ph/Files/Policies/RA\%207076.pdf.

Republic Act No. 7160 : The Local Government Code of 1991. Retrieved from http://ppp.gov.ph/wp-content/uploads/2010/11/The-Local-Government-of-thePhilippines.pdf

Republic Act No. 7942: The Philippine Mining Act of 1995. Retrieved from http://mgb.gov.ph/Files/Policies/RA\%207942.pdf.

Republic Act No. 8371: The Indigenous Peoples Rights Act of 1997. Retrieved from http://mgb.gov.ph/Files/Policies/RA\%208371.pdf.

Ribot, J. C., Agrawal, A., \& Larson, A. M. (2006). Recentralizing while decentralizing: how national governments reappropriate forest resources. World Development, 34(11), 1864-1886.

Salamat, M. (2012). Eight reasons why Aquino's new mining policy is deadlier than the 1995 Mining Act. Retrieved from http://bulatlat.com/main/2012/07/13/eight-reasons-whyaquino\%E2\%80\%99s-new-mining-policy-is-deadlier-than-the-mining-act-of-1995/

Schulte Nordholt, H., \& van Klinken, G. (2007). Renegotiating boundaries; Local politics in post-Suharto Indonesia. Amsterdam: KITLV press

Sidel, J. T. (1999). Capital, Coercion and Crime: Bossism in the Philippines. Stanford: Stanford University Press.

Siegle, J. \& O'Mahony, P. (2006). Assessing the Merits of Decentralization as a Conflict Mitigation Strategy. Washington: USAID. Retrieved from http://www.frpii.org/english/Portals/0/Library/Inter- 
Governmental/Assessing\%20the\%20Merits\%20of\%20Decentralization\%20as\%20a\%20 Conflict\%20Mitigation\%20Strategy.pdf

Sinding, K. (2005). The dynamics of artisanal and small-scale mining reform. Natural Resources Forum, 29(3), 243-252.

Snyder, J. 2000. From voting to violence: Democratization and nationalist conflict. New York: Norton.

The 1987 constitution of the Philippines. Retrieved from http://www.gov.ph/constitutions/the1987-constitution-of-the-republic-of-the-philippines/.

Thelen, K. (1999). Historical institutionalism in comparative politics. Annual review of political science, 2(1), 369-404.

Van der Kroef, J. (1988). The Philippines: Day of the Vigilantes. Asian Survey, 28(6), 630649.

Verbrugge, B. (2014). Capital interests: A historical analysis of the transformation of smallscale gold mining in Compostela Valley province, Southern Philippines. The Extractive Industries and Society, 1(1), 86-95.

Wong, P. K. (2006). Outline of an Anthropology of the Modern Philippine State: Political Decentralization, Internal Pacification, and the Strongmen as State Builders. The Journal of Comparative Asian Development, 5(2), 247-277.

Wurfel, D. (1991). Filipino politics: Development and decay. Ithaca: Cornell University Press.

Yilmaz, S. and Venugopal, V. (2013). LOCAL GOVERNMENT DISCRETION AND ACCOUNTABILITY IN PHILIPPINES. Journal of International Development, 25(2), 227250. 
${ }^{1} \mathrm{~A}$ regularly updated list of all approved mining permits and contracts is available online on http://mgb.gov.ph/lptt.aspx.

${ }^{2}$ At the time Compostela Valley was still part of Davao del Norte province. It only became a separate province in 1998.

${ }^{3}$ The following accounts are based on a combination of key respondent interviews and scarce (online) media coverage.

${ }^{4}$ Those parts of the reservation with low population density that are believed to be highly mineralized, and where mining rights would be awarded through competitive tender (Bagayaua, 2008).

${ }^{5}$ The following accounts are based on a combination of key respondent interviews and scarce (online) media coverage.

${ }^{6}$ This argument is further developed in a seperate contribution that has been submitted for peer review. 